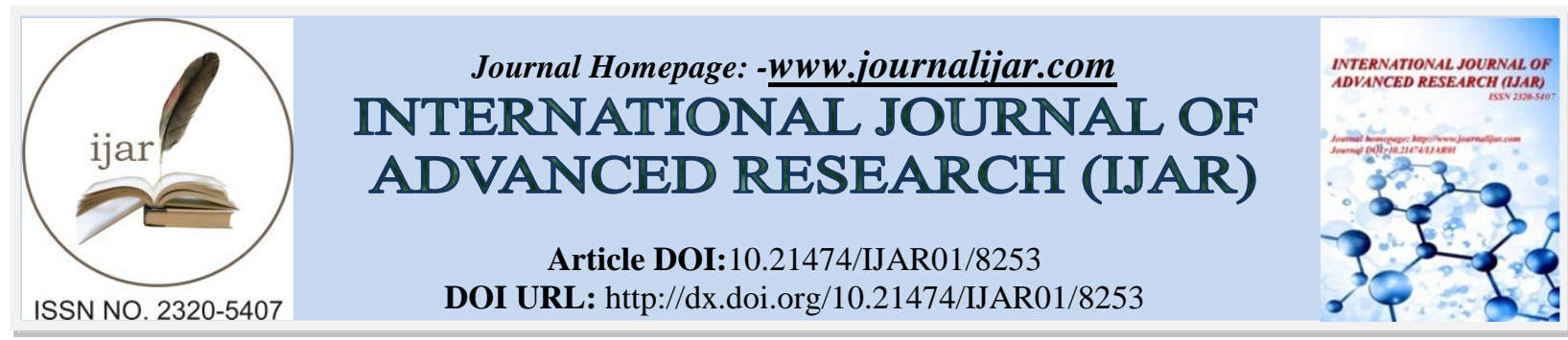

RESEARCH ARTICLE

\title{
ATTITUDE OF PARENTS TOWARDS INCLUSION OF THEIR CHILDREN WITH INTELLECTUAL DISABILITY IN PRIMARY SCHOOL UNDER NAVI MUMBAI.
}

\author{
Jyoti V. Kharat ${ }^{1}$ and Gangadhar. $\mathbf{U}^{2}$. \\ 1. Special educator,nmmc service centre for pwd,vashi, mumbai. \\ 2. Head, Department of Special Education, Sannidhi Centre for Life Skills, Koheda Village, Hayathnagar, \\ R.R.District, telangana State, India.
}

\section{Manuscript Info}

\section{Manuscript History}

Received: 20 October 2018

Final Accepted: 22 November 2018

Published: December 2018

Keywords:-

Attitude, Parents, Inclusive education, intellectual disability.

\begin{abstract}
The study is based on descriptive research design by using Survey method. The sample for the present study consists of 60 parents of intellectual disability whose children are studying in an inclusive school under Navi Mumbai. The purposive sampling technique was adopted for the selection of the ample. The age group of the children is between (6-12) years. The investigator has developed the Questionnaire on attitude of parents towards inclusion of their children with intellectual disability to find out, the extent of attitude of parents towards inclusion of their children with intellectual disability in primary school. The questionnaire contains six domains such as attitude towards rights, Admission Process, Inclusive Education Training, Barrier Free Environment, Schemes and Benefits, and Peer Group Support. The scoring were one for agree and zero for disagree. The maximum score was 42 and minimum was zero. The results revealed that, most parents of children with intellectual disability have positive attitudes toward inclusion in primary school under, Navi Mumbai." An examination of the responses to the domain wise expressing benefits showed that the null hypothesis, there is no significant difference in the attitude of parents towards inclusion of their children with Intellectual disability with respect to parents age is accepted at 0.05 level of significance.
\end{abstract}

Copy Right, IJAR, 2018,. All rights reserved.

\section{Introduction:-}

The status of children with disabilities has undergone significance changes in the past decades ranging from total segregation and charity mode to inclusion with rights mode. The Biwako Millennium Framework (2002) insists on inclusive, barrier free, rights based society. It is important to understand the changing development in the status of persons with disabilities so that we will be in position to keep pace with the changes while teaching children with disabilities especially the children with intellectual disability. The Children with intellectual disability have varying educational needs depending on their abilities, level of retardation and support required by them. All children with intellectual disability do not have the same kind or degree of impairment, which in turn affects development in various areas such as language, motor, social, and cognitive functions. Depending on the specific conditions, the child may need services like speech therapy, physiotherapy, occupational therapy and counseling. The understanding by the

Corresponding Author:-Jyoti V. Kharat.

Address:-Special educator, nmmc service centre for pwd,vashi, mumbai. 
society, which children with intellectual disability have right to education, has evolved in recent years. Some of the major milestones in the development of education of children with disabilities as follow:

1. Article 45 in the constitution of India 1949 vows to provide free and compulsory education to all children between the ages of 6 to 14 years.

2. Salamanca Declaration 1994 reaffirms our commitment to education for all, recognizing the necessity and urgency of providing education to children, youth and adults with special educational needs within the regular education system, and further endorses the framework for action on special needs education, that governments and organizations may be guided by the spirit of its provisions and recommendations (UNESCO, 1994:8)

3. The persons with Disabilities (Equal Opportunities, Protection of Rights and Full Participation) Act, 1995 seeks to ensure appropriate educational provisions for all children with disabilities up to 18 years of age.

4. The National Policy on Disability 2006 emphasizes that children will receive education right from preschool years through primary, secondary, post-secondary and vocational training.

5. Article 24 of the UN-Convention 2008 on the rights of persons with disabilities (UNCRPD) emphasizes the right to education for all children with disabilities to ensure an inclusive education system at all levels and lifelong learning opportunities. Children with disabilities are part of the provisions for free and compulsory primary education, secondary education and receive individual support based on their disability.

6. The SarvaShikshaAbhiyan launched by the Government aims to provide eight years of education up to the elementary level for all children including children with disabilities in the age group of 6-14 years by 2010. Education to be imparted through a range of educational options-from regular schools to alternate schools, special schools, part time classes, community based rehabilitation programmes, open schools and home based education programmes.

7. The amendment of the Right to Education Act, 2009 further strengthens free and compulsory education up to the age of 18 years, including children with special needs, in an appropriate classroom in the vicinity of his/her neighborhood.

However, in India education for children with intellectual disability is provided in a variety of setting keeping in view the change in policies and needs of the community. Thus, the education and training of children with intellectual disability has undergone many changes over a period. . The parents are also thinking about security of the child in the school and they also worry about the child with intellectual disability regarding Individualized education programme for different skills. As a parent it is the responsibility to think, How to cop up their child with other normal child in an inclusive setting, whether their child is receiving appropriate individual education training or and the design of classrooms, method of teaching, instructional programs and activities, barrier free environment, peer group adjustment and so on will be appropriate to their child or not. The parents think that their child will gain and develop in a special school setting only. Most of the parents think that special education training and rehabilitation is best for their children. The parents expressed a concern about whether inclusion would lead to their child's social isolation by other children in a typical class. Concerning these factors the investigator made an attempt to study the attitude of parents towards inclusion of their child with intellectual disability in primary school under Navi Mumbai.

\section{Statement of the problem:-}

The purpose of study is to find out "attitude of parents towards inclusion of their children with intellectual disability in primary school under, Navi Mumbai"

\section{Objective of the study:-}

To know the attitude of parents towards inclusion of their children with intellectual disability in primary school with respect to parent's age.

\section{Null Hypothesis:-}

There is no significant difference in attitude of parents towards inclusion of their Children with Intellectual disability in primary school with respect to parent's age.

\section{Review of Literature:-}

Dimitrova. D.B et.al (2014), quoted thatparents attitude towards inclusiveeducationof children with disability. The study was aimed to explore the similarities and differences in the attitudes of two groups ofparents: a group ofparentsof preschool children and a group ofparentsof school age children. Participants included 88 parents. Generally, many of the parents accept inclusiveeducation, but most of them still think the special school is better place for educationof children with disability. The findings of a study designed to investigate the attitudes ofparentsof "normal" developing children towards the inclusion of children with disabilities into mainstream education in Macedonia. Anke A. et.al 
(2013), studied on Parental attitudes toward the inclusion of children with profound intellectual and multiple disabilities in General Primary Education in the Netherlands. Despite the growing introduction of inclusive education, children with profound intellectual and multiple disabilities (PIMD) are barely included. Because an underlying factor here may be the attitudes of those directly involved, the present study focuses on the attitude of parents and relating variables concerning experience with individuals with disabilities. A self-report questionnaire was completed by 190 parents of children attending general primary schools in the north of the Netherlands. Although parents showed an overall positive attitude, they were most negative about the inclusion of children with PIMD. In addition, no "experience with individuals with disabilities" was slightly negatively associated with the parents' attitudes. To overcome barriers of the inclusion of children with PIMD, such as negative parental attitudes, the outcomes of the present study are discussed in the light of possible interventions. John E et.al (2003), indicated that Parents' attitudes to inclusion of their children with special needs. This study investigated the attitudes of 354 Australian parents who have a child with a disability and who attends a state school in Queensland. The types of disability of the children were broadly in accordance with accepted prevalence figures, except for a greater number reported as having autistic spectrum disorder and fewer students with a learning difficulty/attention deficit hyperactivity disorder. The children were in a range of classes, from special schools to schools where there was in-class help from a special teacher or teacher aide. Many of the parents favored inclusion, some would if additional resources were provided, and a small group of parents favored special placement. There were a limited number of negative attitudes to inclusion reported by the parents, and though some parents thought that some need existed for in-service education about inclusion, this was not a widespread view. Dutta. J. et.al (2011), indicated that Inclusive Education: attitude and problems as perceived by the secondary school students. Inclusive education acknowledges that individual children differ in their abilities and support that each student receives quality education irrespective of their abilities, disabilities, ethnicity, gender and age. In India generally children without disabilities are sent to regular schools and with disabilities are sent to special schools. At present efforts are being made to make education inclusive in nature. Inclusive education means that all children, regardless of their strength or weaknesses are accommodated in a school and become part of the same school community. To achieve this vision we need to take into account what the children feel about such arrangement. The present study was conducted to look into the attitude of students studying in regular schools and those in inclusive schools of Kolkata, towards inclusive education. Information Schedule, Questionnaire and interview were used to collect data. The study provides an overview of attitude towards inclusive education of the students studying in regular schools and those in inclusive schools. The study also provides information about the advantages and disadvantages of the inclusive schools according to the students.

\section{Methodology:-}

The study is based on descriptive research design by using Survey method. The sample for the present study consists of 60 parents of intellectual disability whose children are studying in an inclusive school under Navi Mumbai. The purposive sampling technique was adopted for the selection of the sample. The age group of the children is between (612) years. The investigator has developed the Questionnaire on attitude of parents towards inclusion of their children with intellectual disability to find out, the extent of attitude of parents towards inclusion of their children with intellectual disability in primary school. The questionnaire contains six domains such as attitude towards rights, Admission Process, Inclusive Education Training, Barrier Free Environment, Schemes and Benefits, and Peer Group Support. The scoring were one for agree and zero for disagree. The maximum score was 42 and minimum was zero. The statistical analysis of data was done through computer application using statistical package for social sciences (SPSS). The One way Analysis of Variance (ANOVA) was used to see the relationship between the dependent variables and the independent variables.

\section{Results and Discussion:-}

Table 1:-Mean and Standard deviation of attitude of parents toward inclusion of their children with Intellectual disability with respect to parent's age

\begin{tabular}{|c|c|c|c|}
\hline Domains & rents Age & ean & p. \\
\hline \multirow[t]{4}{*}{ Attitude towards rights } & to $30 \mathrm{yrs}$ & 81 & 10 \\
\hline & $1-40$ yrs & 84 & 36 \\
\hline & $1-50$ yrs & 00 & 00 \\
\hline & Total & 86 & 34 \\
\hline \multirow[t]{3}{*}{ Attitude towards Admission process } & $p$ to $30 \mathrm{yrs}$ & 36 & 22 \\
\hline & $1-40$ yrs & 00 & 16 \\
\hline & $1-50$ yrs & 54 & 29 \\
\hline
\end{tabular}




\begin{tabular}{|c|c|c|c|}
\hline & Total & 98 & 20 \\
\hline \multirow[t]{4}{*}{ titude towards Inclusive Education Training } & to $30 \mathrm{yrs}$ & 63 & 32 \\
\hline & $1-40 \mathrm{yrs}$ & 07 & 11 \\
\hline & $1-50 \mathrm{yrs}$ & 18 & 33 \\
\hline & Total & 20 & 33 \\
\hline \multirow[t]{4}{*}{ Attitude towards barrier free Environment } & to $30 \mathrm{yrs}$ & 90 & 07 \\
\hline & $1-40 \mathrm{yrs}$ & 89 & 19 \\
\hline & $1-50 \mathrm{yrs}$ & 72 & 11 \\
\hline & Total & 05 & 19 \\
\hline \multirow[t]{4}{*}{ Attitude towards Schemes and Benefits } & to $30 \mathrm{yrs}$ & 00 & $\beta 4$ \\
\hline & $1-40 \mathrm{yrs}$ & 60 & $\$ 3$ \\
\hline & $1-50 \mathrm{yrs}$ & 45 & 33 \\
\hline & Total & 83 & 12 \\
\hline \multirow[t]{4}{*}{ Attitude towards Peer Group Support } & to $30 \mathrm{yrs}$ & 82 & 37 \\
\hline & $1-40 \mathrm{yrs}$ & 53 & 15 \\
\hline & $1-50 \mathrm{yrs}$ & 45 & p6 \\
\hline & Total & 57 & $\beta 0$ \\
\hline
\end{tabular}

The above table illustrated that Mean and Standard deviation of attitude of parents towards inclusion of their children with intellectual disability with respect to parent's age. The mean score of parents age upto 30 years 4.81 and its S.D (0.40), the mean scores of parents between (31-40) years 4.84 and its S.D (0.36) and the mean scores parents between $41-50 \mathrm{yrs}$ is 5.00 and its S.D is 0.00 towards the domain attitude of rights, it is also observed that the highest mean score is parents' age between 41-50 yrs 3.54 and its S.D is 1.29 towards the domain attitude towards admission process. Similarly it was also observed that the highest mean score is parents' age between 41-50 yrs 67.18 and its S.D is 1.83 towards the domain attitude towards Inclusive Education Training. It was also indicated that the highest mean score is parents age between 41-50 yrs 3.73 and its S.D is 2.41 towards the domain attitude towards barrier free Environment, therefore it is also observed that the highest mean score is parents age between 41-50 yrs 6.45and its S.D is 0.93 towards the domain attitude towards Schemes and Benefits. Hence it is also observed that the highest mean score is parents' age between up to $30 \mathrm{yrs} 4.82$ and its S.D is 0.87 towards the domain attitude towards Peer Group Support. Overall most of the parents' age between 41-50 yrs has highest mean score towards the attitude of parents towards inclusion of their children with Intellectual disability with respect to parent's age.

Table 2:-Summary of ANOVA of attitude of parents towards inclusion of their children with Intellectual disability with respect to parent's age

\begin{tabular}{|c|c|c|c|c|c|c|}
\hline omains & $\begin{array}{l}\text { burce } \\
\text { of } \\
\text { ariati } \\
\text { on }\end{array}$ & $\begin{array}{l}\text { Sum of } \\
\text { square }\end{array}$ & $\begin{array}{l}\text { egre } \\
\text { of } \\
\text { edo } \\
\text { m }\end{array}$ & ea & t & $\begin{array}{l}\text { evel of } \\
\text { gnifican } \\
\text { ce }\end{array}$ \\
\hline \multirow[t]{3}{*}{$\begin{array}{l}\text { Attitude } \\
\text { owards } \\
\text { rights }\end{array}$} & $\begin{array}{l}\text { etwee } \\
\text { n } \\
\text { roups }\end{array}$ & 0.24 & 2 & 12 & \multirow[t]{3}{*}{0} & \multirow[t]{3}{*}{0.36} \\
\hline & $\begin{array}{l}\text { ithin } \\
\text { roups }\end{array}$ & 6.68 & 57 & 11 & & \\
\hline & otal & 6.93 & 59 & & & \\
\hline \multirow[t]{3}{*}{$\begin{array}{l}\text { Attitude } \\
\text { owards } \\
\text { dmissio } \\
\text { process }\end{array}$} & $\begin{array}{l}\text { etwee } \\
\text { n } \\
\text { roups }\end{array}$ & 7.71 & 2 & 85 & \multirow[t]{3}{*}{$\begin{array}{l}8 \\
4\end{array}$} & \multirow[t]{3}{*}{0.06} \\
\hline & $\begin{array}{l}\text { ithin } \\
\text { roups }\end{array}$ & 77.27 & 57 & 35 & & \\
\hline & otal & 84.98 & 59 & & & \\
\hline $\begin{array}{l}\text { Attitude } \\
\text { owards }\end{array}$ & etwee & 14.65 & 2 & 32 & $\begin{array}{l}0 \\
1\end{array}$ & 0.14 \\
\hline
\end{tabular}




\begin{tabular}{|c|c|c|c|c|c|c|}
\hline \multirow[t]{2}{*}{$\begin{array}{l}\text { hclusive } \\
\text { ducation } \\
\text { raining }\end{array}$} & \begin{tabular}{|l|}
$\mathrm{n}$ \\
roups \\
ithin \\
roups \\
\end{tabular} & 206.94 & 57 & 63 & & \\
\hline & otal & 221.60 & 59 & & & \\
\hline \multirow{3}{*}{\begin{tabular}{|l} 
tttitude \\
owards \\
barrier \\
free \\
nvironm \\
ent
\end{tabular}} & $\begin{array}{l}\text { etwee } \\
\text { n } \\
\text { roups }\end{array}$ & 6.18 & 2 & 09 & \multirow[t]{3}{*}{$\begin{array}{l}6 \\
3\end{array}$} & \multirow[t]{3}{*}{0.53} \\
\hline & $\begin{array}{l}\text { ithin } \\
\text { roups }\end{array}$ & 278.67 & 57 & 88 & & \\
\hline & otal & $\begin{array}{r}2 \\
84.85 \\
\end{array}$ & 59 & & & \\
\hline \multirow[t]{3}{*}{$\begin{array}{l}\text { Attitude } \\
\text { owards } \\
\text { chemes } \\
\text { and } \\
\text { Benefits }\end{array}$} & $\begin{array}{l}\text { etwee } \\
\mathrm{n} \\
\text { roups }\end{array}$ & 6.52 & 2 & 26 & \multirow[t]{3}{*}{6} & \multirow[t]{3}{*}{0.20} \\
\hline & $\begin{array}{l}\text { ithin } \\
\text { roups }\end{array}$ & 113.80 & 57 & 99 & & \\
\hline & otal & 120.33 & 59 & & & \\
\hline \multirow{3}{*}{$\begin{array}{l}\text { Attitude } \\
\text { owards } \\
\text { Peer } \\
\text { Group } \\
\text { support }\end{array}$} & $\begin{array}{l}\text { etwee } \\
\text { n } \\
\text { roups }\end{array}$ & .896 & 2 & $\begin{array}{r}44 \\
8\end{array}$ & \multirow[t]{3}{*}{2} & \multirow[t]{3}{*}{0.77} \\
\hline & $\begin{array}{l}\text { ithin } \\
\text { roups }\end{array}$ & 99.83 & 57 & 75 & & \\
\hline & otal & 100.73 & 59 & & & \\
\hline
\end{tabular}

The table No.2 indicates that, Summary of ANOVA of attitude of parents towards inclusion of their children with Intellectual disability with respect to parent's age. From the table it shows that the obtained F ratio is 1.04 , therefore the calculated value is less than table value ( $>>0.05$ ) with degree of freedom 2 . It is found that there is no significant difference in relationship between the attitude of parents towards inclusion of their children with intellectual disability and parent's age. Hence the null hypothesis (Ho) that there is no significant difference in attitude of parents towards inclusion of their children with Intellectual disability with respect to parent's age is accepted. However with respect to attitude towards admission process obtained $\mathrm{F}$ ratio value is 2.84 , therefore the calculate value is less than table value ( $>0.05)$ with degree of freedom 2(2,57). Hence it reveals that there is no significant relationship between attitude towards admission process and parents age. Therefore the null hypothesis (Ho) is accepted, it is also indicated that However with respect to attitude towards Inclusive Education Training obtained $\mathrm{F}$ ratio value is 2.01, therefore the calculate value is less than table value ( $p>0.05)$ with degree of freedom $2(2,57)$. Hence it reveals that there is no significant relationship between attitude towards Inclusive Education and Training and parent's age. Therefore the null hypothesis (Ho) is accepted. Similarly it is also observed that with respect to attitude towards barrier free Environment obtained $\mathrm{F}$ ratio is 0.63 , therefore the calculated value is less than table value ( $\mathrm{p}>00.5)$ with degree of freedom $2(2,57)$. It is found that there is no significant relationship between the towards attitude of parents and parents age. Hence the null hypothesis (Ho) that there is no significant difference in attitude of parents towards inclusion of their children with Intellectual disability with respect to parent's age is accepted.

It is also shows that with respect to attitude towards Schemes and Benefits obtained F- ratio is $1.63(2,57)$, Therefore the calculated value is less than table value $(\mathrm{p}>0.05)$ with degree of freedom 2 . It is found that there is no significant relationship between the attitude of parents towards inclusive education and parents age. Hence the null hypothesis (Ho) that there is no significant difference in attitude of parents towards inclusion of their children with Intellectual disability with respect to parent's age is accepted. It is also indicated that with respect to attitude towards Peer Group Support obtained F- ratio value is 0.25 , therefore the calculated value is less than table value ( $>0.05)$ with degree of freedom 2(2,57), the results reveals that there is no significant difference relationship between the towards attitude of parents and parents age. Hence the null hypothesis (Ho) that there is no significant difference in attitude of parents towards inclusion of their children with Intellectual disability with respect to parent's age is accepted. The results of 
this study indicate that most parents of children with intellectual disability have positive attitudes toward inclusion in primary school under, Navi Mumbai." An examination of the responses to the domain wise expressing benefits showed that the null hypothesis, there is no significant difference in the attitude of parents towards inclusion of their children with Intellectual disability with respect to parents age is accepted at 0.05 level.

Figure 1:-Graphical representation on attitude of parents towards inclusion of their children with Intellectual disability with respect to parent's age.

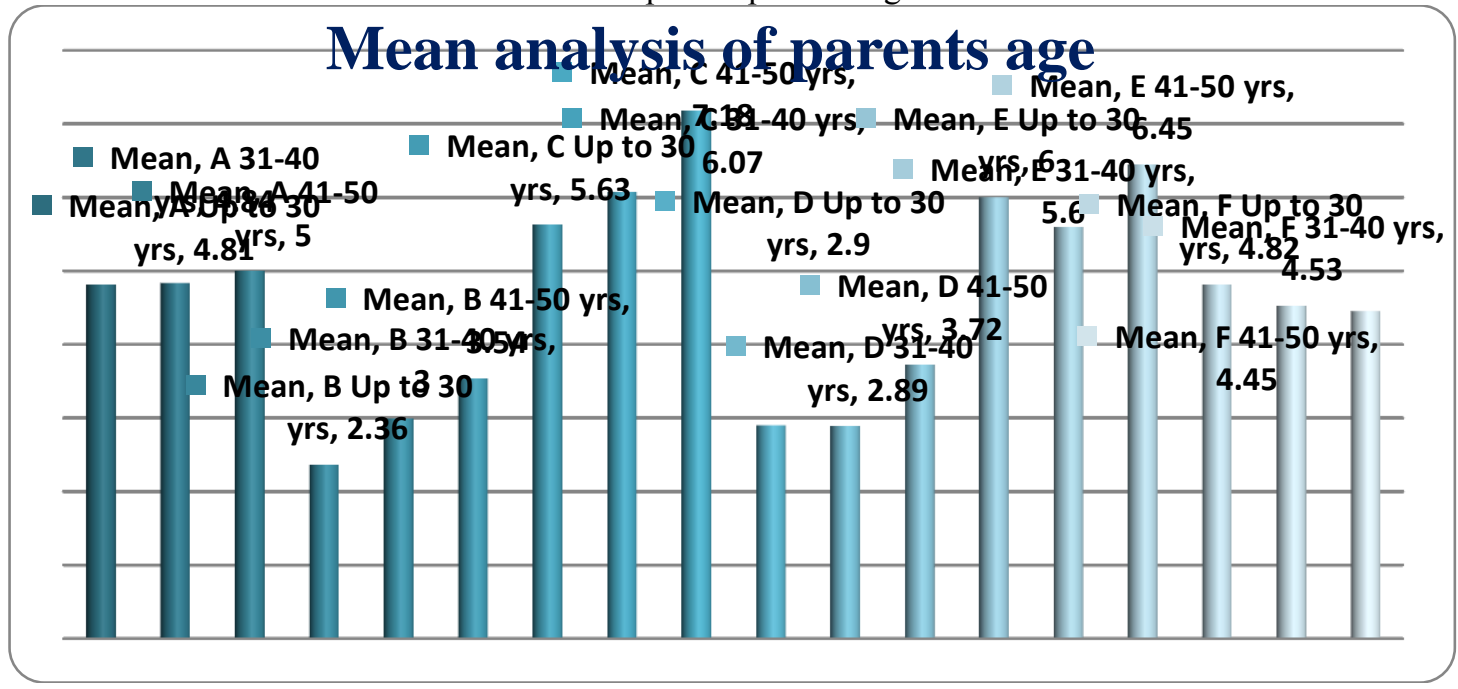

\begin{tabular}{|l|l|}
\hline & Attitude towards rights \\
\hline & Attitude towards Admission process \\
\hline & Attitude towards Inclusive Education Training \\
\hline & Attitude towards barrier free Environment \\
\hline & Attitude towards Schemes and Benefits \\
\hline & Attitude towards Peer Group Support \\
\hline
\end{tabular}

The above graphical representation shows that, the mean analysis of attitude of parents towards inclusion of their children with Intellectual disability with respect to parent's age. It was illustrated that most of the parent's age between 41-50 yrs have highest mean score towards the attitude of parents towards inclusion of their children with Intellectual disability with respect to parent's age.

\section{Discussion:-}

The objective of the study is to find out the attitude of parents towards inclusion of their children with intellectual disability in primary schools under Navi Mumbai. The sample for the present study consists of 60 parents of intellectual disability whose children are studying in an inclusive school under Navi Mumbai. The age group of the children is between (6-12) years. The investigator developed the Questionnaire on Attitude of parents towards inclusion of their children with Intellectual disability in primary school. The questionnaire consists of Six (6) domains. They are A) Attitude towards rights (5), B) Attitude towards Admission Process (6), C) Attitude towards Inclusive Education Training (11) D) Attitude towards Barrier Free Environment (7) E) Attitude towards Schemes and Benefits (7) and F) Attitude towards Peer Group Support (6). The data analysis was done by using statistical packages for social sciences (SPSS) and the results are interpreted and tabulated based on the objective of the study. To know the Attitude of parents towards inclusion of their children with intellectual disability in primary school with respect to parents' age.

The results of the study indicate that, most parents of children with intellectual disability have positive attitudes toward inclusion in primary school under, Navi Mumbai." An examination of the responses to the domain wise expressing benefits showed that the null hypothesis, there is no significant difference in the attitude of parents towards inclusion of their children with Intellectual disability with respect to parents age is accepted at 0.05 level. The parents of the study do not express a major concern about whether inclusion would hurt their child emotionally. However they are concerned whether their children would be socially accepted by other peers without disabilities. Quality of instruction 
and availability of support services create a feeling of uncertainty to parents of children with disabilities about the positive or negative outcomes of inclusion practices. Nevertheless, parents strongly support their children's chance to participate in typical classes, an attitude that to some degree is attributed to their frustration regarding the provision of special policies in Navi Mumbai. Parents appear more confident as regards to equal treatment of their children by teachers in typical classes and their children's acceptance by parents of peers without disabilities.

\section{Conclusion:-}

Studies have shown that the success of the inclusive education depends, to a large extent, on the willingness and the ability of all the stakeholders, most importantly parents, to make accommodations for individuals with special needs. In conclusion, interviews with parents serve to confirm the common agreement on a general right to inclusion and the need for extra support and training to all the stakeholders. That is, despite in principle agreement about inclusion, attitude of parents remained mixed about practices related to inclusion. Research highlights the benefits of efforts on the part of schools to find meaningful and creative ways for parents of children with disabilities to participate and contribute in the school community so that their attitude becomes positive towards inclusion. It is hoped that the factors of parents attitude towards inclusion were proposed in the research can be field tested and thus add another fruitful dimension to the education of students with special education needs.

\section{Limitation of the study:-}

1. The sample size was a small group from an only Navi Mumbai area which is not generalizable urban and rural areas.

2. Another limitation might have to study further comparisons between general and special education.

\section{Implications of the study:-}

1. Future research with larger samples that will include parents of children with all intellectual disability.

2. It also indicates that attitude among primary school teachers play an important role in development curriculum and co-curriculum based on the severity of the disability.

\section{References:-}

1. John E et.al (2003), Parents' attitudes to inclusion of their children with special needs, Vol.3 (2), pp- 122-129.

2. Dutta. J. et.al (2011), Inclusive Education: attitude and problems as perceived by the secondary school students, pp$125-132$

3. Dimitrova. D.B et.al (2014), parents attitude towards inclusiveeducationof children with disability, Vol. 2(1), pp52-55

4. Anke A. et.al (2014), Parental Attitudes toward the Inclusion of Children with Profound Intellectual and Multiple Disabilities in General Primary Education in the Netherlands. Journal of Special Education, pp-1-9. 